\title{
Pengendalian Tegangan Keluaran DC-DC Boost Converter Tipe Voltage Doubler Menggunakan Mikrokontroler STM32F1038CT
}

\author{
Kevin Candra ${ }^{1}$ dan Leonardus Heru Pratomo ${ }^{2}$ \\ Program Studi Teknik Elektro, Universitas Katolik Soegijapranata \\ Jl. Pawiyatan Luhur IV/1 Bendan Duwur, Semarang, 50234, Indonesia \\ kevincandra1002@gmail.com ${ }^{1}$,leonardus@unika.ac.id ${ }^{2}$
}

\begin{abstract}
Five-level inverter is widely used in many industrial applications, for example as a three-phase electric motor drive, PLTS, etc. This inverter works using two separated DC voltage sources in order to form different vol tage level. Five-level inverter using one DC voltage source will be more efficient. A DC-DC boost converter on Voltage Doubler type is used in order to solve the problem. The focus of this research is on controlling the DC-DC boost converter on Vol tage Doubler type. The switch control method uses a shifted pulse width modulation of $180^{\circ}$. To get a suitable output voltage, an output voltage control system is applied. A proportional and integral type control is implemented using STM32F1038CT microcontroller. The output voltage controlled DC-DC boost converter is validated through computational simulation with Power Simulator software and as the final step will be implemented on hardware in the laboratory. Based on the simulation and implementation, Voltage-Doubler type of DC-DC boost converter is able to produce the required output vol tage, which is two times greater than the conventional DC-DC boost converter output vol tage.
\end{abstract}

Keywords- five-level inverter, DC-DC boost converter, Voltage Doubler, STM32F 1038CT

\begin{abstract}
Abstrak-Inverter lima level banyak digunakan untuk aplikasi industri, misalnya sebagai penggerak motor listrik tiga fasa, PLTS, dan lain-lain. Inverter ini bekerja menggunakan dua sumber DC terpisah guna membentuk besaran level tegangan yang berbeda. Inverter lima level dengan menggunakan satu buah sumber DC akan jauh lebih efisien. Suatu DC-DC boost converter tipe Voltage Doubler digunakan untuk mengatasi masalah tersebut. Fokus penelitian ini adalah pada pengendalian DC-DC boost converter tipe Voltage Doubler. Metode kendali saklar menggunakan modulasi lebar pulsa yang tergeser sebesar $180^{\circ}$. Untuk mendapatkan tegangan keluaran yang sesuai, diterapkan sistem pengendali tegan gan keluaran. Kendali tipe proporsional ditambah integral diimplementasikan menggunakan mikrokontroler jenis STM32F1038CT. DCDC boost converter tipe Vol tage Doubler terken dali tegangan keluaran divalidasi melalui simulasi komputasi dengan perangkat lunak Power Simulator dan sebagai tahap akhir akan dilakukan implementasi pada perangkat keras di laboratorium. Berdasarkan simulasi dan implementasi, DC-DC boost converter tipe Voltage Doubler mampu menghasilkan tegangan keluaran sesuai dengan yang diinginkan, yaitu dua kali lebih besar dari tegangan keluaran DC-DC boost converter konvensional.
\end{abstract}

Kata kunci-inverter lima level, DC-DC boost converter, Voltage Doubler, STM32F1038CT

\section{PENDAHULUAN}

Dunia industri merupakan salah satu sektor penunjang perekonomian di Indonesia. Perkembangan industri dalam beberapa tahun terakhir menunjukkan penggunaan multilevel inverter yang semakin meluas pada aplikasi Variable Speed Drive (SPD), PLTS baik off-grid dan on-grid, dan lain-lain [1] - [3]. Kenyataan yang terjadi, pemanfaatan multilevel inverter yang sering diminati dalam bentuk inverter lima level dan terbukti mampu menghasilkan tingkat kecacatan arus dan tegangan yang rendah [4] - [6]. Beberapa topologi yang sering digunakan pada inverter lima level adalah Diode Clamped, Flying Capacitor, H-Bridge Cascade, dan kombinasi beberapa konverter [7], [8].
Inverter lima level pada aplikasi SPD lazimnya menggunakan dua sumber DC terpisah, hal ini menyebabkan inverter lima level memiliki konfigurasi rangkaian yang lebih kompleks dari inverter pada umumnya [9], [10]. Inverter lima level untuk aplikasi PLTS baik off-grid dan on-grid lazimnya menggunakan dua buah $D C-D C$ boost converter konvensional [11] - [13] sehingga akan menyebabkan kompleksitas rangkaian yang lebih tinggi. Solusi untuk mengatasi permasalahan tersebut adalah dengan menggunakan rangkaian DC-DC Boost converter tipe Voltage Doubler. Kontribusi yang dapat diberikan berupa kesederhanaan rangkaian yang menggunakan satu sumber tegangan DC yang dilengkapi dengan sebuah $D C-D C$ converter dan dapat dikendalikan tegangan keluaran untuk menggantikan dua buah $D C-D C$ boost converter konvensional atau dua buah sumber DC. 
Topologi rangkaian aplikasi inverter lima level yang menggunakan dua buah sumber DC pada SPD dapat dilihat pada Gambar 1 dan topologi rangkaian aplikasi inverter lima level pada PLTS yang menggunakan dua buah rangkaian DCDC boost converter konvensional dapat dilihat pada Gambar 2.

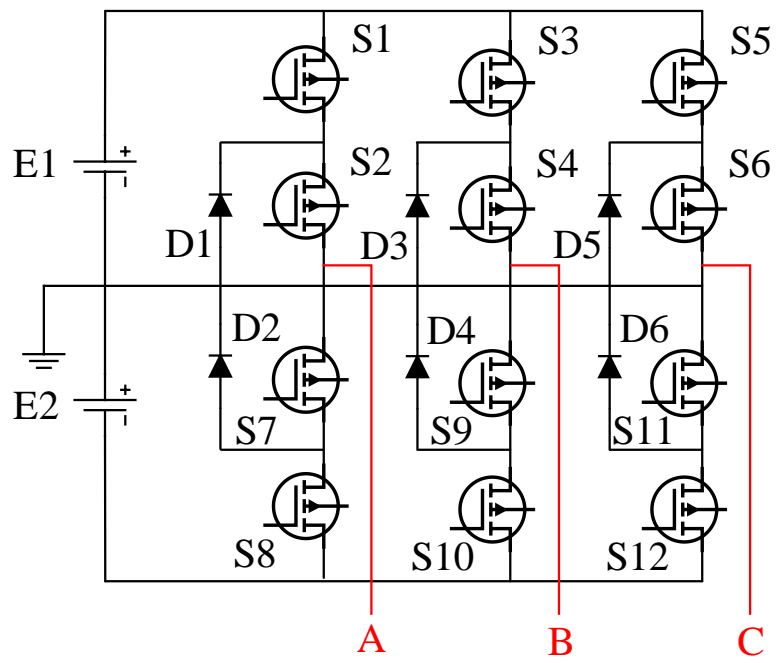

Gambar 1. Aplikasi inverter lima level pada SPD

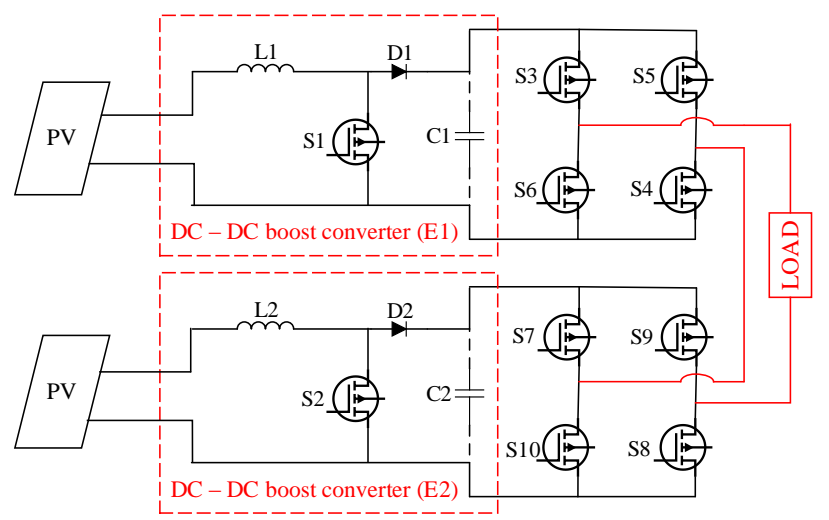

Gambar 2. Aplikasi inverter lima level pada PLTS

Pada prinsipnya DC-DC Boost converter tipe Voltage Doubler merupakan integrasi dari dua buah DC-DC boost converter konvensional yang memiliki tegangan keluaran jauh lebih tinggi dari tegangan masukan dengan menggunakan kendali sinyal Pulse Width Modulation (PWM) [14]. DC-DC boost converter tipe Voltage Doubler memiliki tegangan keluaran dua kali lebih besar dari tegangan keluaran $D C-D C$ boost converter konvensional. Topologi rangkaian $D C-D C$ boost converter yang disisipkan pada modifikasi full-wave Voltage Doubler memiliki keunggulan yaitu dapat diaplikasikan pada tegangan tinggi jika dibandingkan dengan Voltage Doubler konvensional [1]. Topologi tersebut menggunakan aplikasi penyearah modulasi lebar pulsa sinusoidal dengan unjuk kerja tinggi (arus dan tegangan satu fasa). Namun topologi ini memiliki pengendalian yang cukup rumit.

Rangkaian Voltage Doubler tipe rectenna mampu diaplikasikan pada tegangan tinggi walaupun tanpa fitur charge pump capacitor yang umumnya digunakan pada
Voltage Doubler konvensional [15]. Namun rangkaian tersebut sangat bergantung pada beban keluaran. Sedangkan rangkaian Voltage Doubler SEPIC PFC Rectifier juga mampu diaplikasikan pada tegangan tinggi dan mudah dikendalikan, namun memiliki konfigurasi rangkaian yang cukup rumit [16]. Pada penelitian ini, digunakan topologi $D C-D C$ boost converter tipe Voltage Doubler dengan rangkaian yang sederhana dan mudah dikendalikan.

Tujuan dari penelitian ini adalah menawarkan solusi untuk mengatasi dua buah sumber DC terpisah pada inverter lima level dengan menggunakan satu buah sumber DC yang dilengkapi dengan rangkaian $D C$-DC boost converter tipe Voltage Doubler teregulasi tegangan keluaran dengan metode kendali tipe proporsional ditambah integral (PI) yang diimplementasikan dengan menggunakan mikrokontroler STM32F1038CT. Dengan adanya penelitian ini rangkaian akan lebih sederhana, mudah dikendalikan, serta biaya yang murah. Sebagai tahap awal dilakukan analisis $D C-D C$ boost converter tipe Voltage Doubler di bagian II. Simulasi, implementasi, serta pembahasan dilakukan di bagian III.

\section{METODE}

Rangkaian DC-DC boost converter konvensional dapat dilihat pada Gambar 3, terdiri dari satu buah sumber tegangan (Vs), satu buah induktor (L), satu buah saklar aktif (S), satu buah dioda (D), satu buah kapasitor (C), dan satu buah beban resistor (R). DC-DC boost converter tipe Voltage Doubler secara prinsip merupakan gabungan dari dua buah $D C-D C$ boost converter konvensional seperti pada Gambar 4, terdiri dari satu buah sumber tegangan (Vs), dua buah induktor (L1 dan L2), dua buah saklar aktif (S1 dan S2), dua buah dioda (D1 dan D2), dua buah kapasitor (C1 dan C2), dan satu buah beban resistor $(\mathrm{R})$.

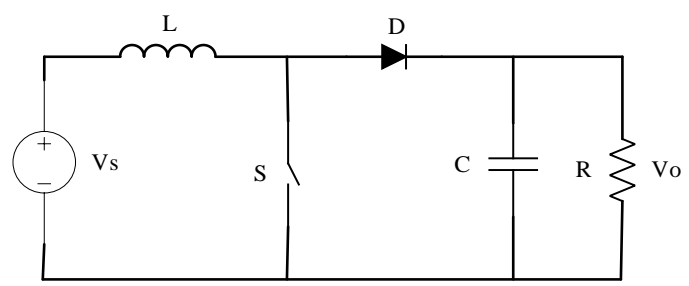

Gambar 3. Topologi rangkaian DC-DC boost converter konvensional

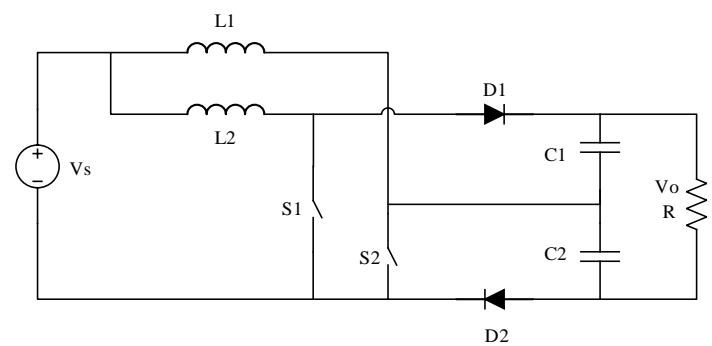

Gambar 4. Topologi rangkaian DC-DC boost converter tipe Voltage Doubler

Topologi rangkaian DC-DC boost converter tipe Voltage Doubler ini terbagi menjadi 4 mode operasi. Mode operasi ini dinamakan mode operasi 1 - 4. Pada mode operasi 1, kedua saklar terkonduksi, sehingga arus mengalir dari sumber DC menuju induktor L1 dan L2, lalu kembali ke sumber tegangan 
(Vs). Mode operasi 1 saat saklar S2 konduksi dapat dilihat pada Gambar 5. Mode operasi 1 saat saklar S1 konduksi dapat dilihat pada Gambar 6. Tegangan pada induktor $\mathrm{V}_{\mathrm{L} 1}$ dan $\mathrm{V}_{\mathrm{L} 2}$ dapat dinyatakan dengan:

$$
\begin{aligned}
& V_{L 1}=L \frac{d i_{L 1}}{d t}=V_{s} \\
& V_{L 2}=L \frac{d i_{L 2}}{d t}=V_{s}
\end{aligned}
$$

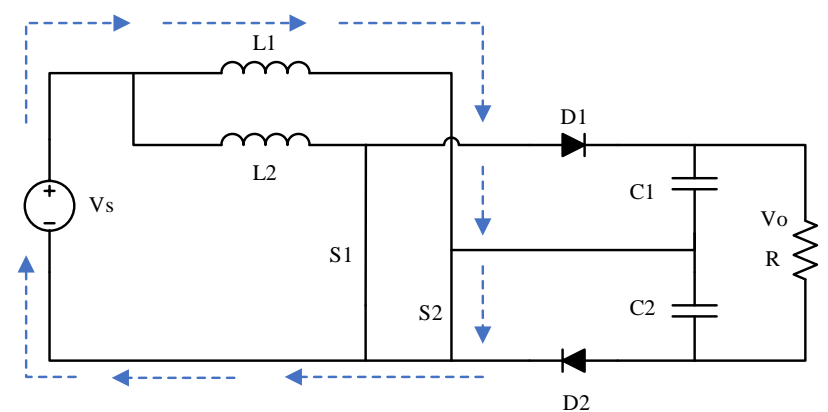

Gambar 5. Mode operasi 1 saat saklar S2 konduksi

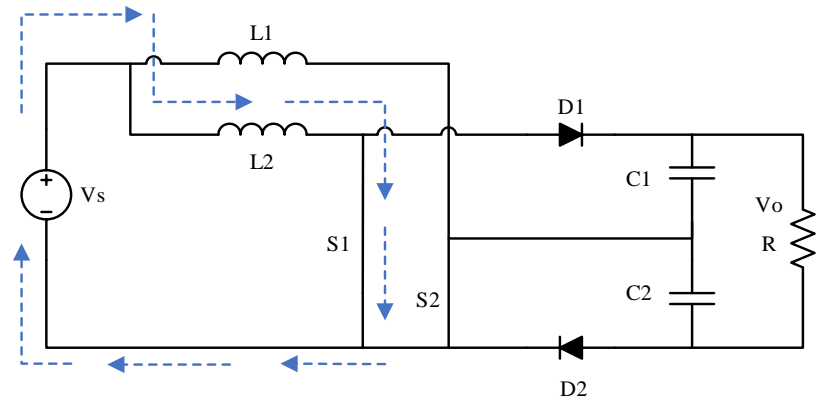

Gambar 6. Mode operasi 1 saat saklar S1 konduksi

Pada mode operasi 2, saklar S2 saja yang terkonduksi, sehingga arus menuju induktor L1 lalu berputar kembali ke sumber tegangan (Vs). Saklar S1 tidak terkonduksi sehingga menyebabkan arus mengalir dari sumber tegangan (Vs) ke induktor L2, kemudian melewati dioda D1, dan menuju ke beban, lalu kembali ke sumber tegangan (Vs) melalui D2. Mode operasi 2 saat saklar S2 terkonduksi dapat dilihat pada Gambar 7. Mode operasi 2 saat saklar S1 tidak terkonduksi dapat dilihat pada Gambar 8. Tegangan pada induktor $\mathrm{V}_{\mathrm{L} 1}$ dan $\mathrm{V}_{\mathrm{L} 2}$ dapat dinyatakan dengan:

$$
\begin{gathered}
V_{L 1}=L \frac{d i_{L 1}}{d t}=V_{s} \\
V_{L 2}=L \frac{d i_{L 2}}{d t}=V_{s}-V_{C 1}
\end{gathered}
$$

Mode operasi 3 merupakan kebalikan dari mode operasi 2, dimana saklar S1 terkonduksi dan saklar S2 tidak terkonduksi. Saat saklar S1 terkonduksi, arus berputar melalui induktor L2 lalu kembali ke sumber tegangan (Vs). Saat saklar S2 tidak terkonduksi, arus mengalir dari sumber tegangan (Vs) ke induktor L1, dan menuju ke beban, lalu kembali lagi ke sumber tegangan (Vs) melalui dioda D2. Mode operasi 3 saat saklar S2 tidak terkonduksi dapat dilihat pada Gambar 9. Mode operasi 3 saat saklar S1 terkonduksi dapat dilihat pada Gambar 10. Tegangan pada induktor $\mathrm{V}_{\mathrm{L} 1}$ dan $\mathrm{V}_{\mathrm{L} 2}$ dapat dinyatakan dengan (5) dan (6).

$$
\begin{gathered}
V_{L 1}=L \frac{d i_{L 1}}{d t}=V_{s}-V_{C 2} \\
V_{L 2}=L \frac{d i_{L 2}}{d t}=V_{s}
\end{gathered}
$$

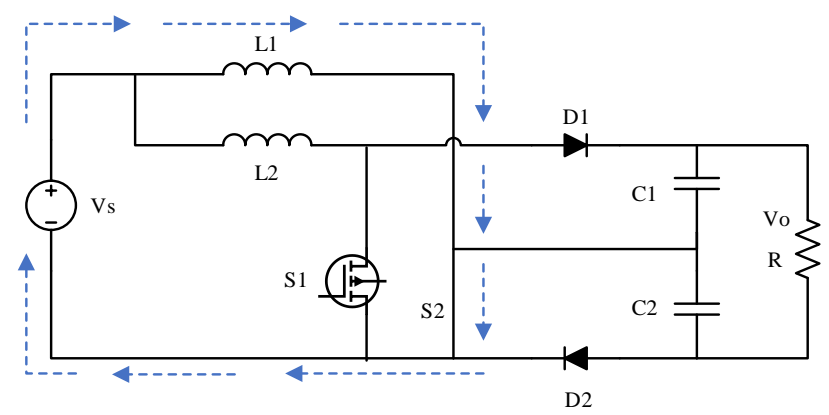

Gambar 7. Mode operasi 2 saat saklar S2 konduksi

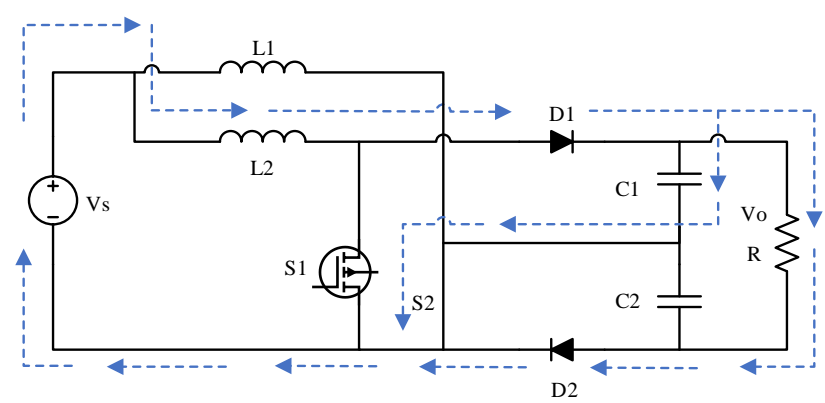

Gambar 8. Mode operasi 2 saat saklar S1 tidak konduksi

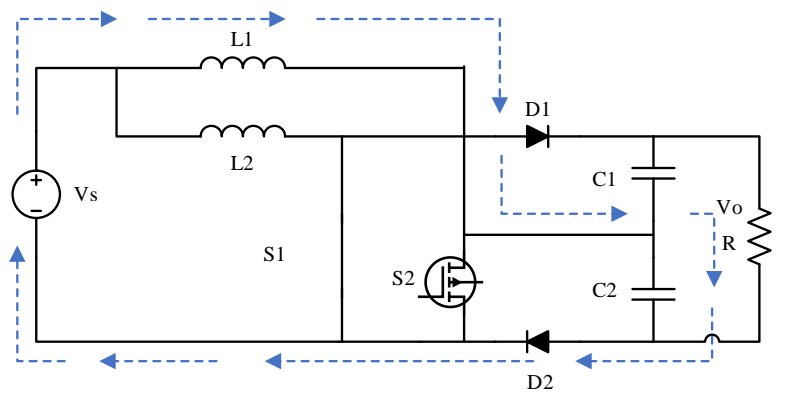

Gambar 9. Mode operasi 3 saat saklar S2 tidak konduksi

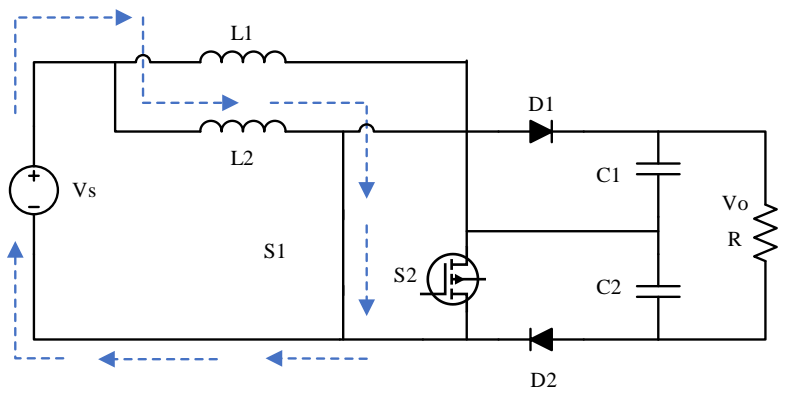

Gambar 10. Mode operasi 3 saat saklar S1 konduksi

Pada mode operasi 4, kedua saklar tidak terkonduksi. Hal ini menyebabkan arus mengalir dari sumber tegangan (Vs)menuju induktor L1, menuju ke beban, dan kembali ke sumber tegangan (Vs) melalui dioda D2. Arus juga mengalir dari sumber tegangan (Vs) ke induktor L2, kemudian melewati dioda D1, menuju ke beban, lalu kembali ke sumber 
tegangan (Vs) melalui D2. Mode operasi 4 saat saklar S2 tidak terkonduksi dapat dilihat pada Gambar 11. Mode operasi 4 saat saklar S1 tidak terkonduksi dapat dilihat pada Gambar 12. Tegangan pada induktor $\mathrm{V}_{\mathrm{L} 1}$ dan $\mathrm{V}_{\mathrm{L} 2}$ dapat dinyatakan dengan:

$$
\begin{aligned}
& V_{L 1}=L \frac{d i_{L 1}}{d t}=V_{s}-V_{C 2} \\
& V_{L 2}=L \frac{d i_{L 2}}{d t}=V_{s}-V_{C 1}
\end{aligned}
$$

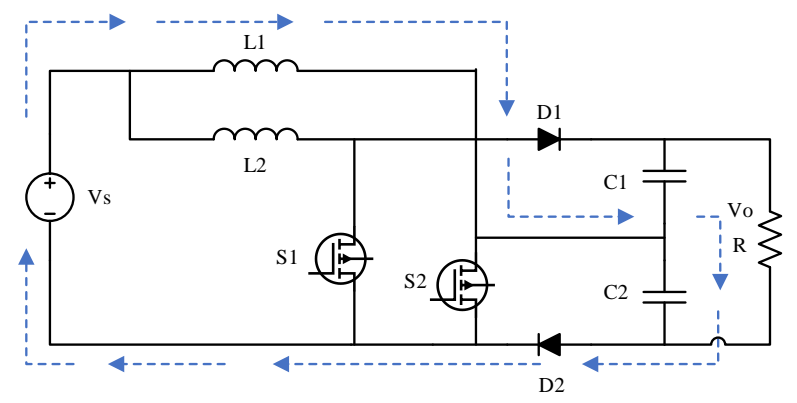

Gambar 11. Mode operasi 4 saat saklar S2 tidak konduksi

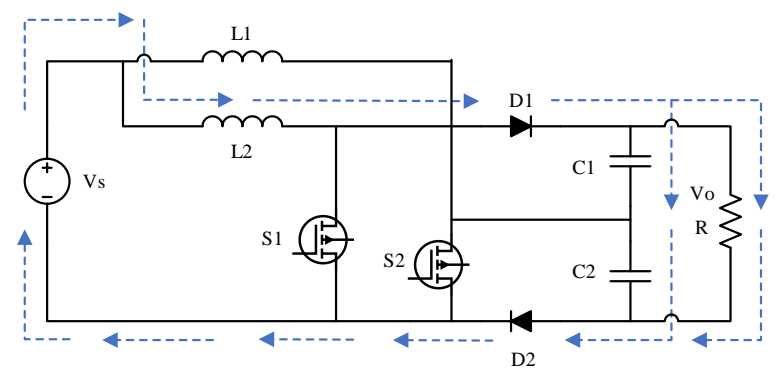

Gambar 12. Mode operasi 4 saat saklar S1 tidak konduksi

Tegangan keluaran $\mathrm{V}_{\mathrm{o}}$ dapat dinyatakan dengan:

$$
V_{o}=V_{C 1}+V_{C 2}
$$

Sedangkan tegangan pada kapasitor $V_{C 1}$ dan $V_{C 2}$ dapat dinyatakan dengan:

$$
\begin{aligned}
V_{C 1} & =\frac{1-D_{S 2}}{2-D_{S 1}-D_{S 2}} V o \\
V_{C 2} & =\frac{1-D_{S 1}}{2-D_{S 1}-D_{S 2}} V o
\end{aligned}
$$

$\mathrm{D}_{\mathrm{S} 1}$ dan $\mathrm{D}_{\mathrm{S} 2}$ adalah duty cycle yang digunakan pada gate saklar S1 dan S2. Jadi, rasio perubahan tegangan M, dapat dinyatakan dengan:

$$
M=\frac{V_{o}}{V_{S}}
$$

Untuk mengendalikan tegangan keluaran pada rangkaian $D C$-DC boost converter tipe Voltage Doubler ditambahkan rangkaian umpan balik. Pada rangkaian umpan balik, tegangan referensi dikurangi dengan tegangan pada kapasitor (tegangan aktual) sehingga menghasilkan error. Error kemudian dikalikan dengan hasil penjumlahan nilai proporsional dan integral. Hasil perkalian tersebut dikomparasi dengan sinyal pembawa sehingga menghasilkan sinyal modulasi lebar pulsa. Sinyal tersebut yang digunakan untuk mengendalikan saklar pada rangkaian daya. Blok diagram sistem kendali $D C$ - $D C$ boost converter tipe Voltage Doubler dapat dilihat pada Gambar 13.

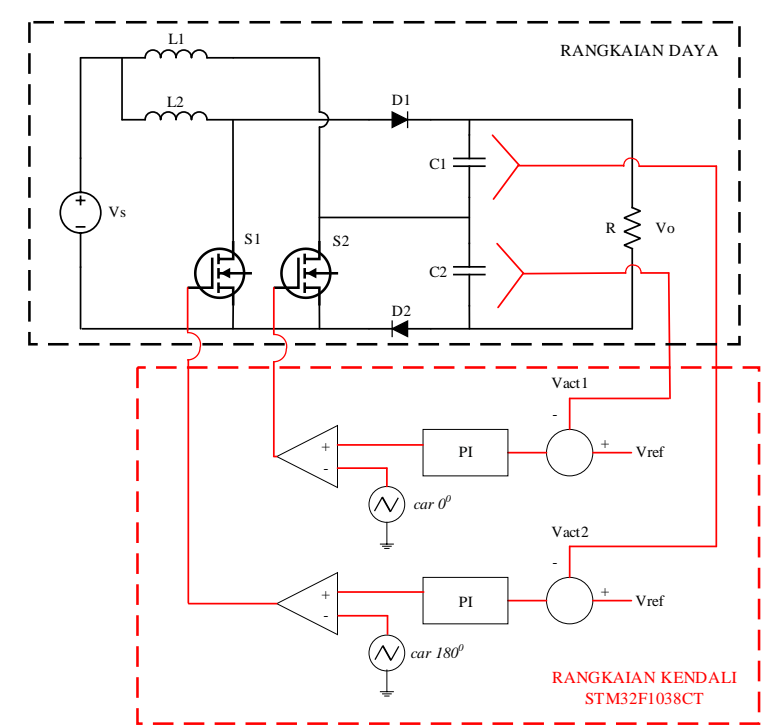

Gambar 13. Blok diagram sistem kendali DC-DC boost converter tipe Voltage Doubler

Berdasarkan Gambar 13 dilakukan suatu pemrograman perangkat lunak dengan menggunakan Arduino IDE yang diimplementasikan pada mikrokontroler STM32F1038CT. STM32F1038CT merupakan mikrokontroler 32 bit dengan harga yang lebih murah dibandingkan dengan mikrokontroler lainnya. Diagram alir pemrograman DC-DC boost converter tipe Voltage Doubler dapat dilihat pada Gambar 14. Vref adalah tegangan referensi. Vact adalah tegangan aktual, kendali yang digunakan yaitu tipe PI, dan sinyal pembawa (car) tergeser sebes ar $180^{\circ}$.

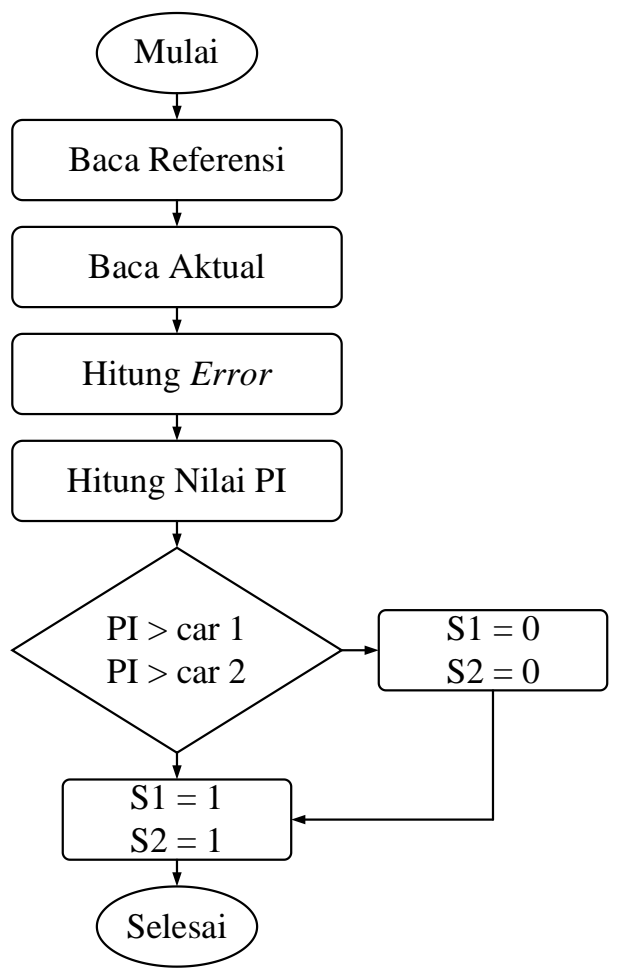

Gambar 14. Diagram alir pemrograman DC-DCboost converter tipe Voltage Doubler 
Langkah pertama adalah pembacaan referensi dan aktual oleh mikrokontroler, lalu penghitungan error dengan mengurangkan tegangan referensi dan tegangan aktual. Setelah itu nilai error akan dikalikan dengan hasil perhitungan nilai PI. Nilai PI kemudian dikomparasi dengan sinyal pembawa (car) dimana car2 merupakan sinyal pembawa yang tergeser sebesar $180^{\circ}$. Jika nilai PI lebih besar dari carl maka saklar S1 akan terkonduksi, dan jika nilai PI lebih besar dari car2 maka saklar S2 akan terkonduksi. Jika kondisi tersebut tidak terpenuhi, baik saklar S1 maupun S2 tidak terkonduksi. Implementasi dari diagram alir pada Gambar 14 adalah sebagai berikut:
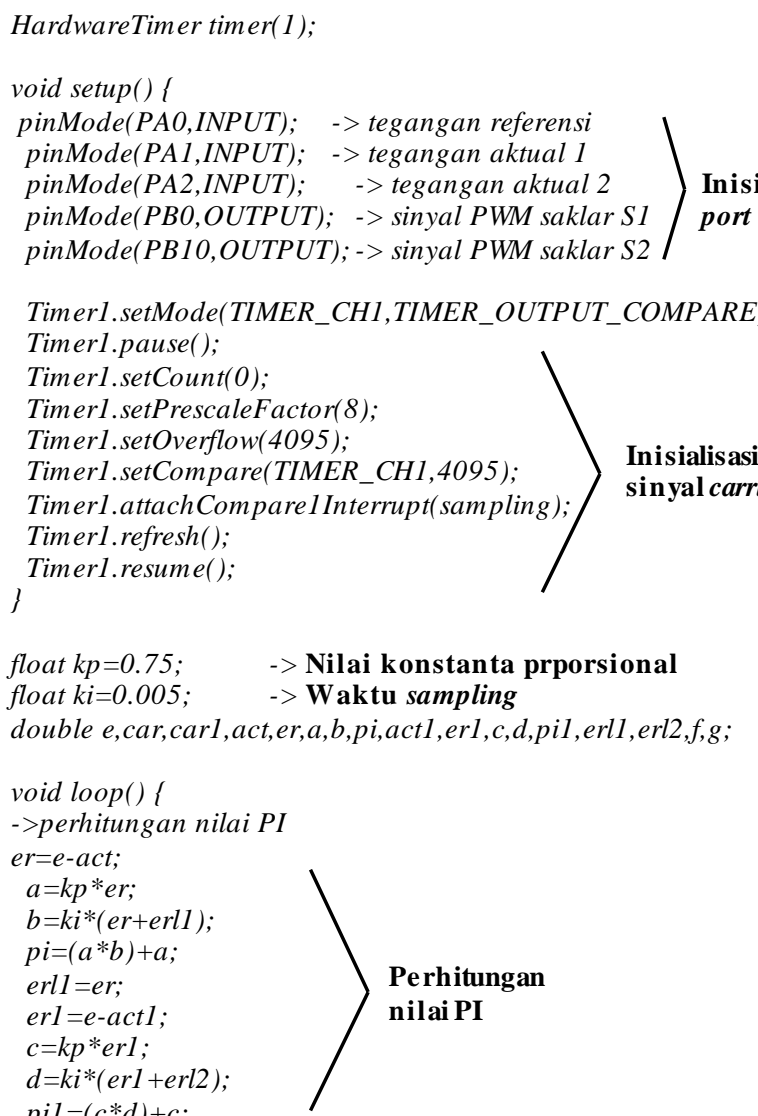

Inisialisasi sinyal carrier \}

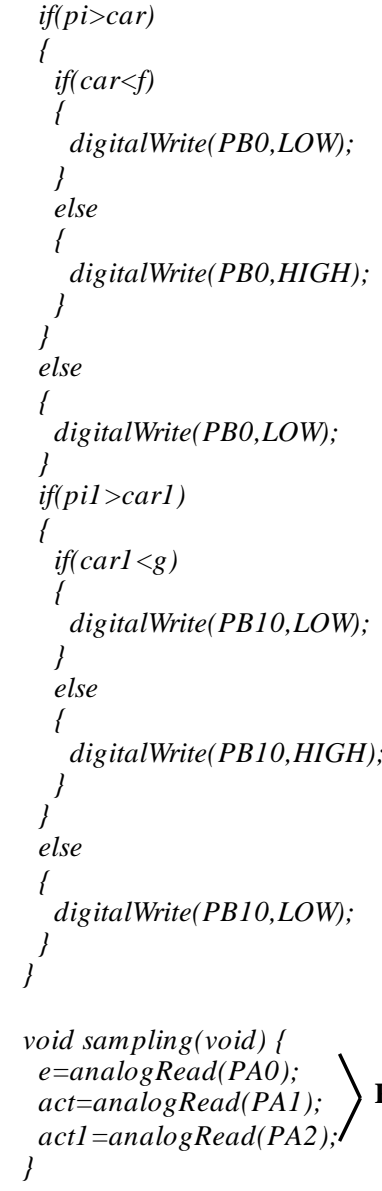

\section{HASIL DAN PEMBAHASAN}

Berdasarkan mode operasi yang telah diuraikan, dibuatlah suatu simulasi komputasi dengan bantuan perangkat lunak Power Simulator dan implementasi perangkat keras untuk memastikan bahwa konsep yang diteliti berjalan dengan baik menggunakan parameter seperti pada Tabel I. Simulasi komputasi ini menggunakan sinyal gelombang DC kotak sebagai tegangan referensinya.

TABEL I. PARAMETER SIMULASI

\begin{tabular}{|l|l|}
\hline \multicolumn{1}{|c|}{ Parameter } & \multicolumn{1}{c|}{ Nilai } \\
\hline Sumber DC & $12 \mathrm{~V}$ \\
\hline Induktor L1 \& L2 & $2 \mathrm{mH}$ \\
\hline Beban Kapasitor & $220 \mathrm{uF}$ \\
\hline Beban Resistor & $100 \mathrm{Ohm}$ \\
\hline
\end{tabular}

Tegangan keluaran pada kapasitor yang diukur dengan sensor disebut dengan tegangan aktual (Vact). Tegangan keluaran dinyatakan terkendali jika tegangan aktual mengikuti bentuk gelombang tegangan referensi (Vref). Hasil perbandingan tegangan aktual 1 dan tegangan referensi dapat dilihat pada Gambar 15, serta hasil perbandingan tegangan aktual 2 dan tegangan referensi dapat dilihat pada Gambar 16. 
Tegangan (V)

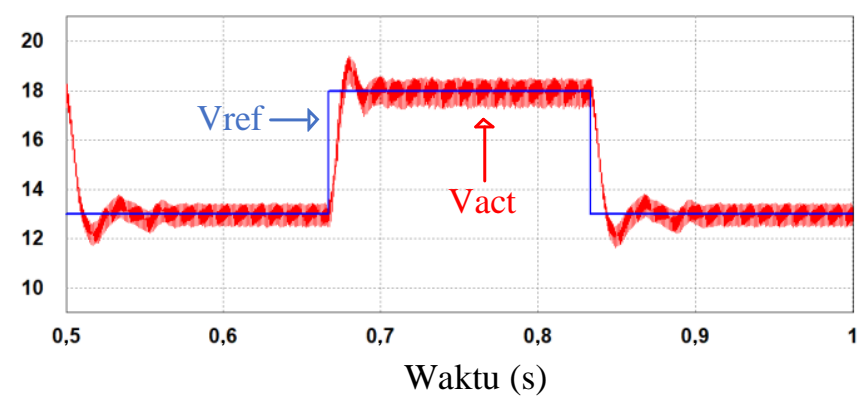

Gambar 15. Perbandingan tegangan aktual 1 dan tegangan referensi rangkaian DC-DC boost converter tipeVoltage Doubler

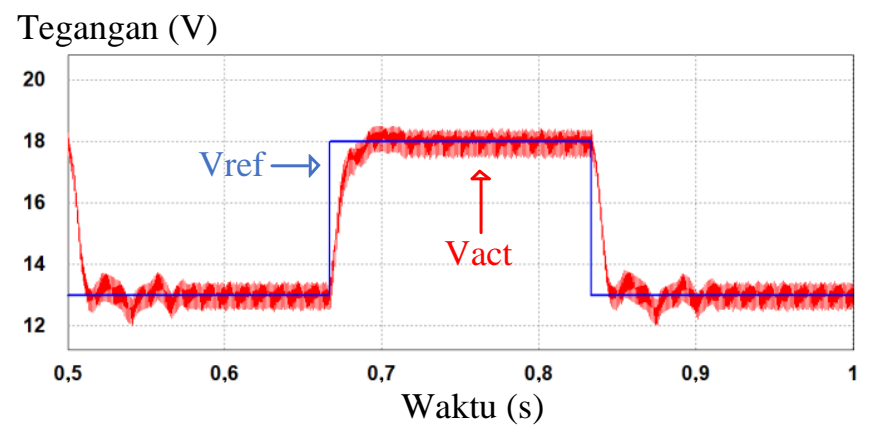

Gambar 16. Perbandingan tegangan aktual 2 dan tegangan referensi rangkaian DC-DC boost converter tipeVoltage Doubler

Selisih dari tegangan aktual dan tegangan referensi tersebut kemudian dikalikan dengan nilai PI yang didapat. Kemudian dikomparasikan dengan sinyal pembawa, hasil komparasi tersebut menghasilkan sinyal modulasi lebar pulsa yang kemudian digunakan untuk mengendalikan saklar S1 dan S2 sehingga didapat tegangan keluaran yang terkendali. Hasil simulasi tegangan keluaran pada rangkaian $D C-D C$ boost converter tipe Voltage Doubler dapat dilihat pada Gambar 17.

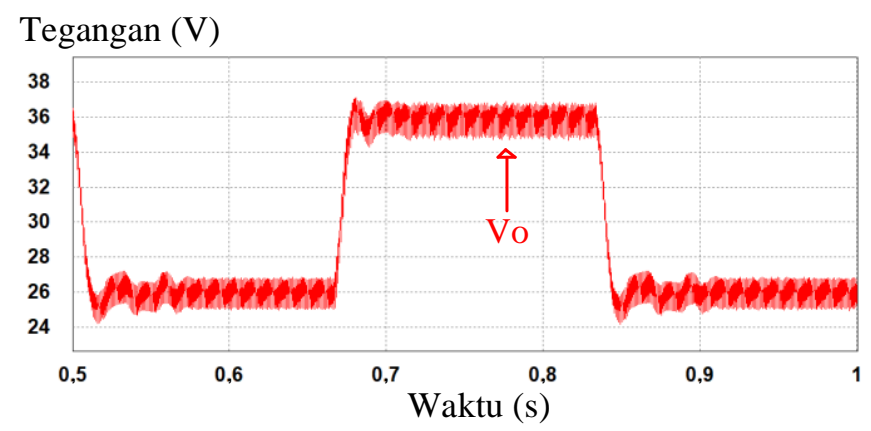

Gambar 17. Tegangan keluaran rangkaian $D C$-DC boost converter tipe Voltage Doubler

Tabel II merupakan parameter yang digunakan pada implementasi perangkat keras. Implementasi perangkat keras dilakukan guna memastikan sistem yang dirancang dapat bekerja dengan baik. Pada implementasi perangkat keras ini, digunakan potensiometer untuk menghasilkan bentuk gelombang DC lurus. Hal ini disesuaikan dengan pengaplikasian sebagai sumber tegangan yang akan dilakukan terhadap inverter lima level.

TABEL II. PARAMETER PERANGKAT KERAS

\begin{tabular}{|l|l|}
\hline \multicolumn{1}{|c|}{ Parameter } & \multicolumn{1}{c|}{ Nilai } \\
\hline Sumber DC & $12,5 \mathrm{~V}$ \\
\hline Induktor L1 \& L2 & $2 \mathrm{mH}$ \\
\hline Beban Kapasitor & $220 \mathrm{uF}$ \\
\hline Beban Resistor & $2200 \mathrm{Ohm}$ \\
\hline
\end{tabular}

Dari parameter pada Tabel II, dilakukan pengaturan pada perangkat keras di laboratorium. Pengaturan dilakukan sesuai dengan blok kendali yang telah dipaparkan pada Gambar 14. Pada perangkat keras, IC IR2110 digunakan sebagai driver dari saklar IRFP460, komponen LV25-P digunakan sebagai sensor tegangan, STM32F1038CT digunakan untuk mengontrol pengendalian saklar. Hasil dari pengaturan perangkat keras dapat dilihat pada Gambar 18. Hasil perbandingan tegangan aktual 1 dan tegangan referensi 1 , serta tegangan aktual 2 dan tegangan referensi 2 pada perangkat keras dapat dilihat pada Gambar 19.

Tegangan aktual 1 dan tegangan aktual 2 pada perangkat keras bernilai $2 \mathrm{~V}$. Sedangkan tegangan referensi 1 dan tegangan referensi 2 pada perangkat keras bernilai $1,99 \mathrm{~V}$. Tegangan keluaran pada perangkat keras bernilai 44,8 V. Tegangan keluaran yang dihasilkan dari implementasi perangkat keras dua kali tegangan keluaran $D C$ - $D C$ boost converter konvensional. Hasil tegangan keluaran pada perangkat keras dapat dilihat pada Gambar 20.

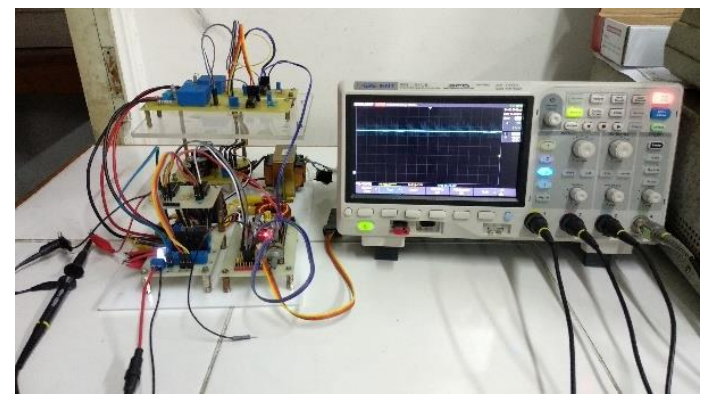

Gambar 18. Pengaturan perangkat keras $D C$-DC boost converter tipe Voltage Doubler

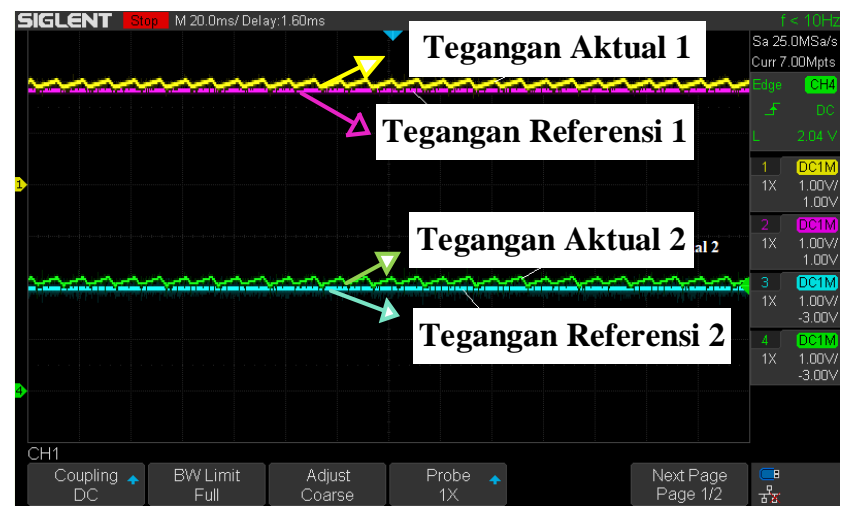

Gambar 19. Perbandingan tegangan aktual 1 dan tegangan referensi 1 , serta tegangan aktual 2 dan tegangan referensi 2 pada perangkat keras 


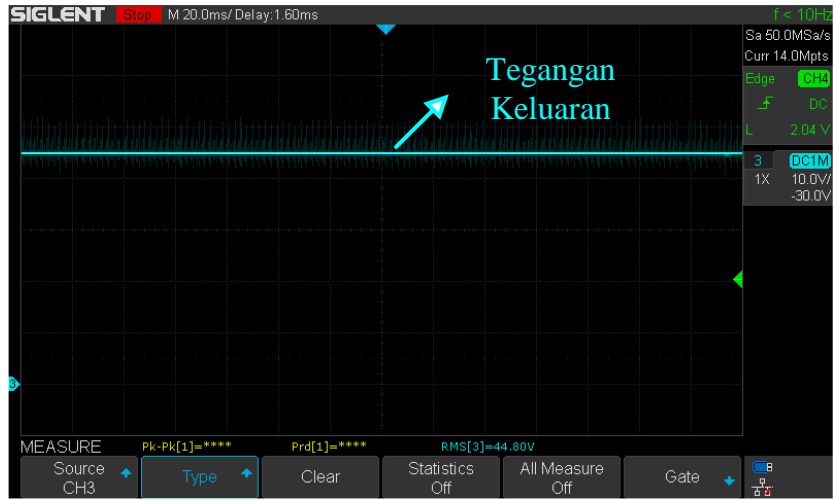

Gambar 20. Tegangan keluaran pada perangkat keras

Dilihat dari rangkaian pada penelitian tentang topologi rangkaian $D C-D C$ boost converter yang disisipkan pada modifikasi full-wave Voltage Doubler [1] memiliki pengendalian yang cukup rumit dan rangkaian Voltage Doubler SEPIC PFC Rectifier [16] memiliki konfigurasi rangkaian yang cukup rumit. Topologi rangkaian yang ditawarkan pada penelitian ini lebih sederhana, sehingga biaya yang dikeluarkan lebih sedikit dan memiliki pengendalian yang mudah dengan metode pengendalian saklar menggunakan modulasi lebar pulsa yang tergeser sebesar $180^{\circ}$.

Dari hasil pengujian yang dilakukan terbukti bahwa $D C$ DC boost converter tipe Voltage Doubler dapat bekerja dengan baik, dilihat dari tegangan aktual yang mengikuti tegangan referensi dan menghasilkan tegangan keluaran dua kali tegangan keluaran DC-DC boost converter konvensional. Inverter lima level pada aplikasi PLTS [11] - [13] menggunakan dua buah $D C$-DC converter konvensional dan pada aplikasi SPD [9] menggunakan dua buah sumber DC agar inverter dapat bekerja sehingga menyebabkan kompleksitas rangkaian yang lebih tinggi. DC-DC boost converter tipe Voltage Doubler dapat digunakan sebagai pengganti dua buah sumber DC tersebut sehingga hanya membutuhkan satu buah sumber DC dengan rangkaian yang lebih sederhana.

\section{PENUTUP}

Pada simulasi dengan perangkat lunak Power Simulator, baik tegangan aktual 1 maupun tegangan aktual 2 mengikuti bentuk gelombang tegangan referensi dan menghasilkan tegangan keluaran dua kali tegangan keluaran $D C$ - $D C$ boost converter konvensional. Implementasi pada perangkat keras terbukti mampu menghasilkan tegangan keluaran dua kali tegangan DC-DC boost converter konvensional. Nilai tegangan keluaran pada implementasi perangkat keras sebesar 44,8 V. Baik tegangan aktual 1 maupun tegangan aktual 2 juga mengikuti bentuk gelombang tegangan referensi dengan nilai tegangan aktual 1 dan 2 berturut-turut adalah $2 \mathrm{~V}$ dan $1,99 \mathrm{~V}$. Dengan hasil tersebut, metode kendali pada rangkaian DC-DC boost converter tipe Voltage Doubler terbukti berhasil dan mampu menghasilkan gelombang keluaran sesuai dengan yang diinginkan. Topologi rangkaian juga menjadi lebih sederhana, mudah dikendalikan, dan biaya murah.

\section{UCAPAN TERIMA KASIH}

Peneliti mengucapkan banyak terima kasih atas pembiayaan dari Kementrian Riset dan Teknologi/Badan Riset dan Inovasi Nasional dalam skema Penelitian Dasar Unggulan Perguruan Tinggi tahun anggaran 2020 dengan Nomor SK: 010/ LL6/PG/SP2H.1/AMD/PENELITIAN/2020.

\section{REFERENSI}

[1] T.-H. Lo, J. Teng, and B. J. Huang, "Interleaved Voltage-Doubler Boost Converter for Power Factor Correction," in 2018 International Power Electronics Conference, IPEC-Niigata - ECCE Asia 2018, pp. 3528 $3532,2018$.

[2] G. M. Idris, I. N. W. S, and I. K. Wiryajati, "Investigasi Sudut Penyalaan Inverter Multilevel dengan Struktur Cascaded H-Bridge untuk Sistem PLTS," Dielektrika, vol. 2, no. 2, pp. 81-90, 2015.

[3] C. Mouliza, M. Vasya, R. S. Lubis, and M. Gapy, "Simulasi Filter Aktif Cascaded Multilevel Inverter Untuk Meminimalisir Harmonisa Pada Motor Induksi 3 Fasa," J. Karya Ilm. Tek. Elektro, vol. 4, no. 3, pp. 19 $29,2019$.

[4] X. Sun, B. Wang, Y. Zhou, W. Wang, H. Du, and Z. Lu, "A Single DC Source Cascaded Seven-Level Inverter Integrating Switched-Capacit or Techniques," IEEETrans. Ind. Electron., vol. 63, no. 11, pp. 7184 7194, 2016.

[5] D. Van Vo, M. K. Nguyen, D. T. Do, and Y. O. Choi, "A single-phase nine-level boost inverter," Energies, vol. 12, no. 3, pp. 1-14, 2019.

[6] B. Maharmi, "Perancangan Inverter Satu Fasa Lima Level Modifikasi Pulse Width Modulation,"J. Teknol. Elektro, vol. 8, no. 1, pp. 24-31, 2017.

[7] Aarya and D. Sankar, "Multilevel Inverters-A Comparative Analysis," in IOSR Journal of Electrical and Electronics Engineering (IOSRJEEE), pp. 43-50, 2017

[8] S. Bhattacharya, D. Mazumder, T. Bose, M. K. Das, S. Ghosal, and S. Jana, "Design of a Cascaded DC High Voltage Generator Based on Cockcroft-Walton Voltage Doubler Circuit," Int. J. Comput. Sci. Eng., vol. 4, no. 6, pp. 56-59, 2016

[9] S. Sau and B. G. Fernandes, "Modular Multilevel Converter Based Variable Speed Drive with Reduced Capacitor Ripple Voltage," IEEE Trans. Ind. Electron., vol. 66, no. 5, pp. 3412-3421, 2019.

[10] L. M. Krishna, J. N. C. Sekhar, A. Sreenivasulu, and G. P. R. Reddy, "Improved Dynamic Performance of a Multilevel Inverter fed Variable Speed Drive using ANFIS and Genetic Algorithms Improved Dynamic Performance of a Multilevel Inverter fed Variable Speed Drive using ANFIS and Genet ic Algorithms," Journal of Automation and System Engineering, vol. 11, no. 4, pp. 308 - 320, 2017.

[11] B. Zhao, A. Abramovitz, C. Liu, Y. Yang, and Y. Huangfu, "A Family of Single-Stage, Buck-Boost Inverters for Photo voltaic Applications for Photovoltaic Applications," Energies, MDPI, vol. 13, pp. 1-21, 2020.

[12] F. Reza Muhammad Rizki, S. Riyadi, and L. Heru Pratomo, "A SPWM Controlled Input in Dual Buck DC-DC Converter - Full Bridge for Single-Phase Five-Level Inverter," J. Phys. Conf. Ser., vol. 1444, no. 1, 2020.

[13] P. Kumari, R. K. Keshari, and S. Banerjee, "Design and implementation of photovoltaic module using multilevel inverter and boost converter," Int. Res. J. Eng. Technol., vol. 4, no. 11, pp. 1064-1068, 2017.

[14] V. A. K. Prabhala, P. Fajri, V. S. P. Gouribhatla, B. P. Baddipadiga, and M. Ferdowsi, "A DC-DC Converter with High Voltage Gain and Two Input Boost Stages," IEEE Trans. Power Electron., vol. 31, no. 6, pp. 4206-4215, 2016.

[15] T. Mitani, S. Kawashima, and T. Nishimura, "Analysis of Voltage Doubler Behavior of 2.45-GHz Voltage Doubler-Type Rectenna," IEEE Trans. Microw. Theory Tech., vol. 65, no. 4, pp. 1051-1057, 2017.

[16] P. J. S. Costa, C. H. I. Font, and T. B. Lazzarin, "Single-Phase Hybrid Switched-Capacitor Voltage-Doubler SEPIC PFC Rectifiers," IEEE Trans. Power Electron., vol. 33, no. 6, pp. 5118-5130, 2018. 